\title{
NETWORK DIPLOMACY: APPROACHES TO THE ISRAELI-PALESTINIAN CONFLICT
}

\author{
Vladimir M. Morozov \\ MGIMO University, Moscow, Russian Federation
}

\begin{abstract}
Introduction. The aim of the article is to to analyze the concept of modern network diplomacy as well as to illustrate possible solution approaches to the Israeli-Palestinian conflict through the abovementioned mechanism. Network diplomacy is defined as the multi-level communication, representation, and negotiation of an idea or a set thereof through a set of actors, which may extend beyond traditional, rigid state sponsored institutions and encompass other actors integrated with the idea or parties involved. Methods and materials. The research involved a combination of analytical empirical research containing justification for case selection and qualitative research. The author mostly approaches the topic through liberal paradigm of international relations, accentuating mutual benefits of international cooperation, arguing that flexible formats of diplomacy can be an effective way to help states to interact with each other in an honest manner and support nonviolent solutions to conflicts. Analysis. The analysis is based mainly on case study research, which helped to generate the results. The article will be structured in several parts. The introduction will render an overview of the network diplomacy concept followed by a historic background of the Israeli-Palestinian conflict and its ideological underpinnings, and so inform a set of theories as pertaining to the potency of network diplomacy in the solution process, which will be outlined in the parts following it. These theories will then be evaluated in the context of the overall environment and specific cases - NGOs as a reach out function in water management at the municipal level, academic institutions establishing communication channels independent of the larger political environment, and a short summary of European Union outreach to non-state actors as an illustrative case of state to non-state actor diplomacy. Moreover, the article includes the study of citizen diplomacy, civil society-based approaches, economically driven incentives and other cultural initiatives such as sports-based diplomacy as possible mechanisms. Results. Network diplomacy may feature a multi-pronged approach to diplomacy represented through a mixture of, for example, state actors and nongovernmental organizations (NGOs). Network diplomacy is particularly potent in spreading ideas as it allows engagement of a multitude of actors directly, and is subject to comparatively low transaction costs. Network diplomacy appears to be a promising approach to the solution of the Israeli-Palestinian conflict which is characterized by juxtaposing ideological underpinnings in addition to issues of realpolitik, and a multitude of actors including non-state actors.

Key words: network diplomacy, Israeli-Palestinian conflict, NGOs, citizen diplomacy, sports diplomacy, academic diplomacy, conflict resolution.

Citation. Morozov V.M. Network Diplomacy: Approaches to the Israeli-Palestinian Conflict. Vestnik Volgogradskogo gosudarstvennogo universiteta. Seriya 4. Istoriya. Regionovedenie. Mezhdunarodnye otnosheniya [Science Journal of Volgograd State University. History. Area Studies. International Relations], 2021, vol. 26, no. 1, pp. 145-156. DOI: https://doi.org/10.15688/jvolsu4.2021.1.13
\end{abstract}

УДК 327.56

Дата поступления статьи: 20.03.2020

ББК 66.49

Дата принятия статьи: 21.09.2020

\section{СЕТЕВАЯ ДИПЛОМАТИЯ: ПОДХОДЫ К ИЗРАИЛЬСКО-ПАЛЕСТИНСКОМУ КОНФЛИКТУ}

\section{Владимир Михайлович Морозов}

Московский государственный институт международных отношений (университет) МИД России, г. Москва, Российская Федерация 
Аннотация. Целью статьи является попытка проанализировать концепцию современной сетевой дипломатии с последующей имплементацей ее механизмов при разработке подходов к разрешению израильскопалестинского конфликта. Сетевая дипломатия определяется как многоуровневое общение, представление и обсуждение какой-либо идеи или набора таковых посредством группы субъектов, которые могут выходить за рамки традиционных, жестких, находящихся на бюджетном финансировании институтов и охватывать других субъектов, связанных с этой идеей или вовлеченными сторонами. Таким образом, сетевая дипломатия может предусматривать комплексный подход к дипломатии, представленный, например, сочетанием государственных субъектов и неправительственных организаций (НПО). Сетевая дипломатия особенно эффективна в распространении идей, поскольку она позволяет напрямую вовлекать множество субъектов и связана со сравнительно низкими операционными издержками. Исходя из вышесказанного, сетевая дипломатия представляется перспективным подходом к урегулированию израильско-палестинского конфликта, который характеризуется наложением идеологических основ в дополнение к вопросам реальной политики и множеством субъектов, включая негосударственные субъекты.

Ключевые слова: сетевая дипломатия, израильско-палестинский конфликт, НПО, общественная дипломатия, спортивная дипломатия, академическая дипломатия, урегулирование конфликтов.

Цитирование. Морозов В. М. Сетевая дипломатия: подходы к израильско-палестинскому конфликту // Вестник Волгоградского государственного университета. Серия 4, История. Регионоведение. Международные отношения. - 2021. - Т. 26, № 1. - С. 145-156. - (На англ. яз.). - DOI: https://doi.org/10.15688/jvolsu4.2021.1.13

Introduction. After the end of the Cold War, the world witnessed an unprecedented wave of globalization, powered by new advancements in information and communication technologies. While countries were growing ever more interconnected, so did the problems and challenges facing humanity.

As of now, it is extremely difficult to imagine any international issue settled by a single nation acting alone. The role of the global community and interstate cooperation in today's globalized world is hard to deny. The evolving nature of international relations and global challenges breeds the necessity of finding new types of cooperation and establishing more efficient mechanisms of tackling the issues on the global agenda in accordance with the current conditions on the world arena. Network diplomacy is one of such mechanisms.

Methods and materials. Given a range of assumptions about the quality of actors and their interactions, a hypothesis was analyzed and finally corroborated by empirical case studies and in qualitative research. The author mostly approaches the topic through liberal paradigm of international relations, accentuating mutual benefits of international cooperation, arguing that flexible formats of diplomacy can be an effective way to help states to interact with each other in honest manner and support nonviolent solutions to conflicts. Giving particular examples of how network diplomacy mechanisms can be applied to the Israeli-Palestine conflict makes the article more practically-oriented.
Analysis. The very concept of diplomacy can be defined as the mechanism of representation, communication and negotiation through which States and other international actors conduct their affairs and settle differences. The means through which these functions are carried out have been strongly challenged since the late 1980s.

There are today more and newer types of actors which can, and sometime must be engaged. The channels and means of communication, as well as the issues themselves have evolved and required a significant adaption effort from state and non-state actors.

In order to refresh the sacred concept of diplomacy, Jamie Metzl developed and suggested the concept of Network Diplomacy, suggesting that in our times, public diplomacy has evolved to the point that it had become more "ideally suited for a network orientation" [10, p. 77].

In our contemporary world, technological progress and social evolutions, including the dilution of information, values, and ideologies as well as the mass-scale empowerment of individuals, have led to traditional diplomacy becoming a much more fragmented and decentralized field.

Indeed, diplomacy has become a field which now requires reaching out to newer and larger groups of people and organizations. A field which has also been expected - and has often failed to adequately exploit some of the newly-created spaces and grey areas of our international system (social media, public diplomacy, etc.). 
As such, the concept of network diplomacy is often considered to be a modernized version of yesterday's traditional - and at times almost mythical - diplomacy. It is modernized in the sense that it is now expected to provide appropriate mechanisms and answers to face three major developments:

1. The necessity for increased cooperation in a volatile and highly populated globalized international environment.

Nowadays, the world is facing a wide range of issues which are intricately linked to seemingly unrelated issues: from poverty, under-development, food insecurity or environmental concern can now stem radicalization, terrorism, refugee crisis, conflicts and various other potential issues. In short, security threats have become uniquely multidimensional, and what may have required one or two parties in the past may require dozens of actors from various backgrounds today: poverty, environment (e.g. military conflicts).

More importantly, the issues of our current system transcend physical borders, which have now become the last remains of yesterday's sovereignty. The cyberpace, organized crime, terrorism, and other significant and potentially destabilizing issues can cross borders and spaces quite easily, thus exploiting gaps (physical, material, legal, etc.) before traditional actors can identify and address these issues.

2. The current evolution of technologies, most particularly in the fields of information and communication dissemination.

It is a trite truism, that the emergence of the internet and modern information technologies have significantly altered our social and communicative patterns, and thus our global environment. In this context, its influence on the public diplomacy appears evident. The amount of information is not longer an issue, and the sources have become multiple.

Yesterday, diplomatic apparatuses required complex, sometime covert sources and information to adequately address the challenges they faced, often to extract limited information from finite sources, with a significant risk. Today, sources are seemingly infinite, what could be gathered yesterday from a unique source through an intelligence service can now be replaced by a public diplomatic network with local communities and non-state actors. Journalists and other civil society-based networks can sometime provide and disseminate valuable knowledge to and from diplomatic institutions more efficiently than the likes of Benjamin Franklin or Anatoly Dobrynin could have ever conceived.

As a particularly accurate prediction formulated by HSBC's marketing team in the late 1990s: data, communication and networks will become the currency of tomorrow. Today, communication is without a doubt one of the central pillars of the network diplomacy. It is the main feature of modern world, that is why, public diplomacy has transformed from a high-risk / high cost information gathering and analysis product into a low-cost / low-risk information gathering and dissemination process. If anything, today's modern network diplomacy has in many ways started to replicate some of the marketing and public relations strategies developed by corporations from the 1980s.

3 . The expanding number of relevant international actors and sources of influences.

In the past decades a wide range of nonstate actors such as multinational corporations (MNCs), international media outlets, nongovernmental organizations (NGOs), armed nonstate actors (ANSAs), religious groups and other civil society organizations (CSOs) as well as international and intergovernmental organizations have stepped more profoundly into the multilayered field of global (geo)politics and therefore global diplomacy.

Their influence is at times comparable, even stronger (for short or extended period of times) to that of certain states or groupings of states. A highly contrasting example would be to compare the power of a corporation such as Facebook, Microsoft or Google and their global reach and influence to that of Lesotho, St. Kitts and Nevis or Suriname. In this context, it seems clear that the formulation of an effective diplomacy in the $21^{\text {st }}$ century needs to devote more attention to the multiplication of "engage-able" actors, their interests, reach, influence, power and strategies, be they a group of small / medium powers such as the group of Landlocked Developing Countries or a set of CSOs such as the Vienna NGO Committee.

The Network. "Disseminating information is spam, network is strategic", as Rhonda Zaharna states. 
According to Metzl, a network, in the context of diplomacy, is a "set of interconnected individuals who occupy analogous positions in institutional or social structures and create new community relationships that build upon, democratize, and magnify existing social frameworks" [10].

He further adds that the principle of functioning relies on the logic that "the more appropriate people they connect, the more useful and attractive the network becomes to others".

The best illustration of this principle finds its origins in computer science. Robert Meltcafe, credited with the creation of the Ethernet network, stated a simple principle - Metcalfe's Law which can be defined as the impact, or reach of a network is the square of the number of nodes comprised within that network. Simply put, the more people are integrated into a network, the more beneficial and powerful a network becomes. David Reed formulated a similar principle taking more groups and sub-groups into account, which is more particularly applicable to social network. Reed's Law, to avoid unnecessary complications, also states that a network has an exponential increased impact (reach) than the number of nodes (connections) comprised within it.

In any cases, most networks applied in the context of diplomacy would have the following features:

1) flexibility;

2) effectiveness;

3 ) act across traditional boundaries;

4) lower cost of common activity.

A Government Model of Networking. The "networkization" of governmental and institutional actions is a natural part of the globalization, consequently, if a government wants to successfully occupy, seize, retain or develop within newly-created socio-political and ideological spaces, it must embrace the concept of external networks - with the implicit acceptance of reduced sovereignty from national boundaries - thus integrating the major shifts resulting from fast-paced and scarcely regulated globalization as the basis of its diplomatic ideology.

"A shift in conceptual models must also be accompanied by new relationships among government foreign policy actors, as well as between these actors and global constituencies. Governments need to nurture their own internal networks and link them to broader networks outside of government", as Jamie Metzl states [10].

Therefore, it could be concluded from this first part that network diplomacy is an institution's diplomatic activity, which transcend traditional frameworks and borders, in order to create networks of actors from varied backgrounds with varying degrees of power, skills and audiences, through the creation or adherence to new channels of communication and cooperation with other international actors on a virtually infinite spectrum of issues. This would be conducted in order to take advantage to the added exponential value which a network possess from the number of nodes / actors it comprises.

Among the greatest tests of diplomacy and problem-solving capabilities within the international system, one can hardly ask for better than the Israel - Palestine Peace Process. Undeniably the longest and most complex international negotiation process since the end of World War II.

The modern state of Israel, and with it the Israeli-Palestinian conflict, found its ideological conception in Theodor Herzl's 1896 treatise Der Judenstaat (The State of the Jews) arguing for the existence of a Jewish nationality, and that those of Jewish nationality should aspire to form a state of their own, preferably in their historical homeland of Palestine. Only such a state would be able to provide the umbrella of protection necessary for Jews to freely practice their religion and customs free of anti-Semitism prevalent in Europe [14, p. 23].

Herzl's ideas were well received among existent Zionist groups, and helped propel the formation of the Zionist Organization and First Zionist Congress, which elected him as its first president. Spurned by ideological conviction the first (1882-1903) and second Aliyah (1903-1913), the immigration of Jews to the land of Israel, saw the agglomeration of a considerable Jewish community in Palestine. The specter of socialism loomed over these communities often manifested as kibbutz, collectivist farming communities with a religious stint.

Much bitterness stems from juxtaposing British statements, in the 1915 McMahon letters Britain offered its support for an Arab state with ambiguous borders - in exchange for a revolt against the Ottoman rule, in the context of the first World War. Conversely, the 1917 Balfour 
declaration expressed sympathy for a Jewish homeland situated in Palestine. Arab-Jewish tension and unclear governance characterized the decades leading up to the formal conception of modern Israel in 1948 through UN Resolution 181 partitioning Palestine into two states, one Jewish, the other Arab.

Demographics guaranteed the continued presence of a sizable Arab minority in the Jewish state; the partition was supported by Jewish leaders and rejected by Palestinians and the Arab league, laying the foundations for a region-wide conflict which remains unsettled. The establishment of Israel followed in May 1948 and was preceded by a flaring up of violence following the acceptance of the two-state solution; the foundation of Israel was marked with celebration by Jewish migrants and became known as al-Nakba among Palestinians - the catastrophe.

Marred by wars with its Arab neighbors, Palestinian uprisings and Israeli repression, Israel's history since then has not lacked in controversy, much of it rooted in the continuing failure to resolve the Palestinian issue. An array of institutions has since sprung up surrounding the conflict on both sides of the issue raising structural obstacles to a traditional solution, e.g. nationalist and/or religious extremists deriving their existence from the conflict and holding positions intrinsically unacceptable to the other side, foreign and domestic. Both sides found their claim based on national legitimacy grounds (history and/or demography). Due to the decade-long unsuccessful resolution process a fear of banalization may manifest itself, apparent in a sense of passive acceptance, lethargy, and hopelessness amidst continued conflict.

At present Palestine exists as a de jure sovereign state, with the last presidential election having taken place in 2005, the central Palestinian in control of the West Bank and Gaza under Israeli blockade and Hamas control.

Theory: There can be two opposing views on the role of network diplomacy as a contribution to solving the conflict. The first one is that network diplomacy could be of value to the IsraeliPalestinian conflict. Given the comparatively large number and diverse nature of actors involved in the Palestinian issue, including NGO's, business groups, solidarity and Protest movements, think tanks and media actively influencing the peace process, of domestic, regional, and foreign origin, network diplomacy is not a potential path to a solution, but a precondition.

A successful policy must not simply be pursued on the state-to-state level, but take a more grass roots approach and involve drivers of public opinion necessary to shape the consensus intrinsic to any satisfactory solution. Classic state-to-state diplomacy may stall without an exogeneous shock to the system, which is exceedingly unlikely given that all major global actors with relevance to the issue are already involved. As such, it appears unlikely that a classic diplomatic approach could yield an argument that has not been heard yet.

Alternative theory is that there is little value to Network Diplomacy in the IsraeliPalestinian conflict. The Palestinian issue does not lack dialogue between non-state actors, however state-to-state conversation has been lackluster. The present dialogue is characterized by distrust and a mutually perceived lack of cooperation; negotiations have generally been brokered by third parties and failed. It is hard to imagine a sustainable co-operative solution as long as state institutions are at odds with each other [4, pp. 97-115].

Thus, any progress made on the nongovernmental level would not be translated well into political reality. It is unlikely that nongovernmental actors could force institutional change due to decade-long entrenchment. Solutions thus have to be reached on the state-tostate level, diplomacy on other levels is not likely to yield lasting impacts.

Towards a Solution: Is network diplomacy a pre-condition for lasting change? Above theories may be empirically contrasted by considering a set of examples in which network diplomacy has been used, and whether a sustainable solution has been brought about in these cases, or, if this was not the case, if this was due to a lack of success in reaching a solution, or due to roadblocks after the solution had been reached, and to what degree state institutions were involved in either point.

As such, the conflict will not be considered as a single discrete unit but an agglomeration of smaller conflicts which may have a solution independent of the overarching problem of statehood; principles which may aid other solutions will be deduced. 
Some roadblocks inhibit both state and nonstate actors in the region, first amongst them a lack of trust and shared agenda, combined with a rejection of joint struggle, entrenched and institutionalized conflict with the threat of ostracization looming over divergent voices. It remains to be seen if networks have reached sufficient maturity to fulfil one of the underlying principles of network diplomacy, that, as per Jamie Metzl, "those organizations that best respond to new realities will be most able to advance their interests globally" [10].

Case: Joint NGOs initiate stable cooperation in water management. A wellpublicized example of complementary cooperation on the state and non-state level is cooperation in the space of water management and related environmental issues. As water is an imperative issue for both sides, and co-operations decreases the risk of armed conflict over resources which are in principle sufficient to satisfy all stakeholders, a solution could be a catalyst for peace building.

However state-to-state diplomacy has failed to produce mutually desirable outcomes in the given case, Brooks and Trottier in a 2014 study of the Israeli-Palestinian conflict in the space of water resources write that "[in the case of Israel and Palestine] the greatest barrier appears to be fear, not of what may emerge from the negotiations but of coming to the negotiation table at all" due to fear that negotiations may jeopardize the status quo and expose their constituencies to harm. Further, both sides also feel trepidation over whether an agreement can be sold to their respective electorates [1, pp. 211-223].

In an informal context, a 1994 conference initiated by Israel / Palestine Center for Research and Information (IPCRI), a joint Israeli-Palestinian NGO and non-governmental think tank, both Israeli and Palestinian delegates have agreed on the need for co-operation in water management and assessed the issue as one integral to the structural peace-building process.

Thus, in the light of the obstacles to direct diplomatic discourse outlined above, NGOs have emerged as a key complement to the official peace-building effort. The 1993 Oslo peace process saw the parallel formation of a numerous joint Israeli-Palestinian NGOs to deal with environmental issues by aiding policy development, rendering technical expertise as well as practical implementation of trans-boundary water projects where the presence of state actors could be perceived as inflammatory.

This ability to operate independently of state institutions has been an asset in times of diplomatic crisis; most joint NGOs have survived the violence of the second Intifada in the early 2000s, and thus kept a channel of communication open despite a looming diplomatic crisis. Thus, NGOs in the water space constitute a link between Israel and Palestine on both the governmental and societal level.

As such a significant contribution to desecuritization, the process of rendering an issue non-threatening transforming it from a task of security policy to one of civil society, can be observed - as NGOs rendered their services independent of the larger security environment, a precondition for the formation of civil structures. In the same vain a certain degree of trust is fostered, and working networks established, which are of economic value and function as part of a reinforcing cycle of co-operation through the establishment of bilateral structures (i.e. the more bilateral structures there are the more efficient co-operation becomes, the easier it is to establish further bilateral structures where needed).

A specific example of a dual pronged approach of NGO and state action in the water space is the "Good Water Neighbors" project launched by the "Friends of the Earth Middle East" (FoEME) in 2001 with the explicit goal of stimulating trilateral co-operation among Israelis, Palestinians and Jordanians in the water space as part of a larger peace building process, stating that "while at a national level a conflict can prevent progress in problem-solving, at the community level there can remain a willingness to cooperate" [2, pp. 65-67].

Within this context, the Mayors of the border communities Baka el Sharkia and Baka el Gharbia-Jat on the Palestinian and Israeli side respectively agreed to sign a memorandum of cooperation. However, administrative obstacles persist (e.g. in the construction of new infrastructure), underlining the penultimate role of government in the realization of initiatives brought forward by civil structures.

Case: Academic institutions drive dialogue beyond ideological and tangible barriers. A main roadblock to the peace building 
process is a lack of post-agreement reconciliatory structures fostering dialogue between formerly opposing parties; these structures can also function as a driver of peace by laying a foundation (i.e. through a bilateral communication channel) for jointly coming to terms with the past, on equal footing.

Academic institutions are intrinsically tasked with the study and dissemination of information relating to political processes of note, and the establishment of objective truth in environments marred by highly subjective rhetoric. In the IsraeliPalestinian case academic co-operation may be of particularly high value to the Palestinian side which lacks the educational and technical capacity of Israeli researchers, thus enabling downstream knowledge flow to civil society at large. Empowering Palestinian academics may not exclusively aid unilateral advocacy, but also provide the tool for guided bi- and multi-lateral communication with Israeli and international counterparts.

Malul and Schwarz in a 2010 study of Israeli-Palestinian cooperation argue that simple communication is not efficient in peace building as "previous experience in cooperation between Palestinians and Israelis does not alter perceptions about the barriers", and that "even if the individuals' subjective beliefs and attitudes change because of previous experience, their perceptions regarding the objective barriers to cooperation are still not affected" [7, pp. 75-92]. Thus, communication channels must be such that tangible aspects to cooperation can be tackled in addition to ideological ones, which is the case for academic cooperation.

To this end the "Arava Institute for Environmental Studies" (AIES) constitutes a practical example of academic linkage in the Israeli-Palestinian arena with a focus on establishing practically feasible, goal driven communication channels. Ajoint project of Israeli, Palestinian and Jordanian academics the AIES has rendered university education to a diverse student body, approximately equally split between Israeli, Arab and overseas students, since 1996, and has been in constant crisis ever since.

A key component of the institute's mission is to help its alumni network with each other postgraduation. According to a longitudinal study of the institutes operation by Schoenfeld et al.
"Through this strategy, the institute does not rely on the idealism of its students, but gives them practical educational and professional assistance", much in accordance with the need to tackle tangible challenges jointly with ideological considerations outlined above. Overall, the task for academic institutions is to establish practical, issue focused communication channels across ideologies, which are not part of classic diplomatic reach-out [9, pp. 125-137].

Case: Network diplomacy as a way of reaching out to exogeneous actors. Nontraditional actors are not constrained to their immediate system (the Israeli-Palestinian Arena in the given case), but may reach out globally. European Union (EU) policy towards the Palestinian issue constitutes an illustrative example in this regard, extending beyond traditional state actors to encompass non-state actors (NSA).

Hereby, a two-pronged approach is pursued on the input side consultation with NSAs adds legitimacy to policy by considering the needs of stakeholders, on the output side NSAs benefit from EU programs or funding opportunities.

There is thus a dedicated interface for the communication between a state actor, the EU, and non-state actors expressing implicit support for the notion of NSAs as a further avenue of diplomacy.

Other possible solutions. In 1947 , as an attempt to solve a conflict, a network of states and international organizations (through the United Nations) reflected upon the issue and put it on the global agenda. The idea scribed and drafted as Resolution 181 (A/RES/181) of the UN General Assembly was the result of a simple, mostly state comprised network engaging into a peace negotiation. Half a century later, a similar process, more complex network, extending its membership to international organizations, observers, NGOs, and implicitly social and traditional media, continues to work upon the issue.

While many diplomatic efforts have been made to achieve a two-state solution, (1991 Madrid Conference; 1993 Oslo Accords, 2000 the Camp David Summit, 2001 Taba Negotiations in early, 2002 the Arab League proposed Arab Peace Initiative, and the latest 2013-2014 peace talks) have all failed.

In trying to understand the now historical set of failures and precedents, one must seek for 
contrast between what was discussed in the beginning as an appropriate response to our current global environment, and the answers provided by all the failed negotiations.

In doing so, one can observe that the members comprised in the networks are all from limited backgrounds. They are all state-centric or state-based actors, thus reducing their reach to the state and state-centric institutional aspect of the issue. As such, one could conclude or formulate the hypothesis that the lack of a diversified group of members or nodes, may limit the ability of all these negotiations to fully address the sum of multidimensional issues and grievances from both sides.

Indeed, it is not quite so difficult to imagine that the process which would allow civil society organizations and representatives to engage mutually, may lead to more accountability and/or pressure on other types of actors involved in the process. If, as an example, various groups from the Israeli and Palestinian societies, were somehow able to reach an agreement or understand on certain points, and if, business or socio-economic actors and pillars were able to reach compromises on similar or different issues, this would not only force state negotiator to include these in the process (thus making the process more adequate to the situation) but it would also create a pressure and legitimacy which the state negotiators would have to either satisfy or accept to jeopardize [11, pp. 438-452].

What could then be done to achieve such a multi-dimensional, diverse peace process? An answer would be to engage on varied front, through different, informal, time spaced processes that cement the basis for further negotiations. These could include citizen diplomacy, NGO and civil society-based approaches, economically driven incentives and other cultural initiatives such as sports-based diplomacy.

Citizen Diplomacy and the Culture of Peace. Illustrating the previous point, is the citizen-led diplomatic process witnessed in the Israeli-Palestinian conflict. The disillusionment resulting from the Oslo Accord and the interruption of the peace process pushed civil society on both sides of the conflict to take leadership and start searching for a dialogue and joint actions to create a culture of peace in the absence of political will.

Citizen diplomacy in the Israeli-Palestinian conflict plays a significant role. It basically aims at providing opportunities for interacting and working together on the creation of a culture of peace. The culture of peace being an essential component, it must be promoted through citizen diplomacy or people-to-people initiatives in order to overcome barriers.

The first example is the BSMZ campaign. It was a joint campaign between Jewish Israelis citizens from Mevaseret Zion and Palestinians from Beit Surik. The whole idea of this campaign was making participants dropping their ideology about the conflict and gather people.

One of the campaign's goal was to involve all kind of citizens from both sides including nonelite citizens. Naturally, the BSMZ campaign is based on the Track II diplomacy which refers to "non-governmental, informal and unofficial contacts and activities between private citizens.

A deeper analysis into the previous example demonstrates that citizen diplomacy can be an effective tool for the promotion of peace and resolution in a conflict, as well as for the creation of a peace culture which would later become the basis of any lasting peace initiative and drive.

Civil Society. Similarly, NGOs and civil society-based approaches can be a powerful tool of network diplomacy. When it appears impossible or particularly challenging to resolve a conflict at the governmental level, NGOs can exert political infuence by introducing topics into international debate, setting agendas, fighting for new norms, proposing and facilitating negotiations, pressuring reluctant governments to make changes and using the social and ideological reach.

The cooperation of Israeli and Palestinian NGOs on issues which are of great concern for both parties represents a way out of crisis. In 1999, a conference organized by the Peace Research Institute in the Middle East (PRIME) brought together over 40 Israeli and Palestinian NGOs that were interested in cooperation on a variety of cooperative projects involving educational, economic, human rights, healthy, environment and social issues [6, pp. 87-89].

An example of active work has been going between ecological NGOs, which worked toward the protection of the ecosystem shared between Israel and Palestine. For many periods of times, these NGOs have worked and collaborated on projects aimed at enhancing not only the environment, but also peaceful relationships 
between the neighbours using environmental concern for their respective lands as a driver and common point of agreement.

The relationship between the conflict and the degradation of the environment in the West Bank and Gaza Strip can be identied as a significant issue. Moreover, many expressed their belief that water shortage, pollution and deforestation are both consequences and drivers to further conflicts between the two nations.

Later on, Palestinian and Israeli NGOs working on this issue, agreed that expansion of settlements was detrimental to the shared environment as natural areas were being destroyed in order to build new infrastructures, more often than not in violation with Israeli, Palestinian and international laws.

Sports diplomacy. Similarly to politics and ideology, sports has a specific way to trigger and excite passions. Over the centuries, if not more, sports have proven its ability to be an effective and powerful political tool. One needs only to look at John Carlos' 1968 First at the Olympic Games to illustrate African American Civil Rights issues in the US, or the heavily charged and tense Olympic confrontations between the Soviet Union and the United States during the Cold War, to fully appreciate this.

This ability to excite and sometimes derail passions has also significantly impacted the Israeli Palestinian issue. The 1972 Summer Olympics, represented a window of opportunity for Black September terrorist organization to spread fear and gain global attention when they executed 11 Israeli athletes and their coach. The refusal to integrate Israel into the groups of Middle Eastern countries in FIFA, or the inclusion of Palestine in the Asia Cup represents the potential symbolic significance of sports in any major political struggle or process.

When in 1972 Israeli sportsmen were allowed to participate it was widely viewed as an implicit recognition of Israel on the world scene. This aggravated the Israeli-Palestinian conflict, as Palestine could not take part in this event and perceived its non-invitation as a strong political defeat and provocation.

When earlier this year Palestinian flags were raised and waved by a significant crowd, in a frantic manner at the Asian Cup in Australia, one could not perceive or appreciate a certain sense of victory for those defending Palestinian statehood. In fact, in the minds of many, these may represent a much stronger global signal and have a much more powerful reach through these newly-created spaces previously discussed (such as social media) than Palestine's entry and recognition by UNESCO Member States. That is because, while many people in East Asia had never heard of Palestine before, they were now aware of its existence. In fact, one could probably argue that more people in this part of the world heard from Palestine's presence at the Asia Cup than those who ever heard about Palestine being granted a seat at UNESCO. In this context, the participation of Palestine to this tournament was particularly for those advocating for its statehood as Palestine's first match took place less than two weeks after the rejection of its latest bid for statehood.

Sports, football in particular, are in today's highly decentralized and individually empowered world an important tool to bring an echo to any cause and the issue of Palestinian statehood represents no exception.

Apart from promoting and preserving identities, sport can also be used to help solve conflicts between groups. It has demonstrated its ability to help bring people together even in times of conflicts. The Sochi Olympics had Ukrainian athletes participating in them, without fear of reprisal or consequences, and when American and Russian fencers faced each other for the gold in Rio, it was in a sportsmanship and respectful manner.

And if such has been the case for many issues, with such heavy connotations, in a time where sports, and most particularly football, are among the very few common values and vectors able to transcend networks and borders, it is of primordial importance, for these attempting to solve the Israeli-Palestinian conflict to understand the importance of engaging and reaching global crowds through such initiatives [13].

Economic actors and liberal incentives. For much of the past century, the conflict between Israelis and Palestinians has been a defining feature of the Middle East. Despite billions of dollars having been spent to support, oppose, or seek to resolve it, the conflict has endured for decades, with periodic violent eruptions. Each violent uprising leads Palestinian GDP per capita 
to fall by about $46 \%$ while Israeli GDP per capita falls by about $10 \%$. Assuming that mutually beneficial economic activity could spare interest to peaceful resolution of the conflict let's take a look at such option.

Proceeding from existing economic peace projects Israel and Palestine need to deepen such efforts and strengthen economic ties. In his election campaign Benjamin Netanyahu stressed that: "We must weave an economic peace alongside a political process. That means that we have to strengthen the moderate parts of the Palestinian economy by handing rapid growth in those area, rapid economic growth that gives a stake for peace for the ordinary Palestinians".

Currently, international aid is the lifeline of the Palestinian authority. By 2008, international aid accounted for more than $60 \%$ of Palestinian GNI. In contrast, the RAND Corporation estimated that if a peaceful solution is achieved, both parties would benefit significantly in both absolute and GDP per capita terms. While income for the average Israeli would have increased by about \$2,250 (about 5\%), the average Palestinian's income would rise by about $\$ 1,100$ (about 36\%) [3, pp. 132-150].

Among the biggest and most successful economic initiatives in place are joint industrial parks, Valley of Peace Initiative, Olives of peace (joint Israeli-Palestinian business venture to sell olive oil). While industrial parks and Valley of Peace Initiative are government-backed initiatives, which create jobs in Israel and the West Bank, parties need to move further toward private companies' partnership. Some tensions revolved around existing government economic projects. One example was the construction of Rawabi, a new city, which Israel partially helped to construct. It was intended to house 40,000 people in its first phase and more in the future; the first 700 homes had already been built by 2015 . However, some claimed that conflicts with Israeli authorities had prevented it from having any roads other than a single-lane farm road, and that water access issues had not been resolved.

One of such examples was the Olives for peace initiative. Palestinians have benefited from large amounts of venture capital available through Israeli contacts. Israeli involvement began by benefiting from the labour costs and salary levels in Palestinian society, where various Israeli businesses have already outsourced some business. Over time, the project became a partnership, owing to a large number of new Palestinian college graduates who studied information science and needed new business opportunities. Such private companies' projects also bind economics, science, education together and is a viable way to create an additional reason for peaceful conflict resolution [5, pp. 263-274].

The World Future Council took part in creating the best ways of introducing a Palestinian currency. Such a currency would be in accordance with the Paris protocol and international law. It would have several advantages for Palestinian economy: reducing exchange costs, ensuring seignior age profits from money creation stay in Palestine, and contributing to greater economic flexibility. It would enable the Palestinian Monetary Authority (PMA) to become a central bank, a lender of last resort to the banking sector which could also spend directly into economy. Such spending would not be inflationary if it enabled unused productive facilities and many unemployed Palestinians to produce new goods and services.

In an official visit to Israel John Kerry declared that improving the economic situation would create a favourable atmosphere for political progress while economic recovery would help create an atmosphere of trust between the two parties. There is a need for projects that include agricultural, industrial, tourism and collaborative projects, in addition to employment centres near major cities "so as to exempt Palestinians from working inside Israel" facilitating the transit through the crossings and trying to find foreign investment [12].

There are also various NPOs which aim to promote economic partnerships between Israelis and Palestinians (e.g. Israeli-Palestinian Chamber of Commerce and Industry, ECF "Economic Cooperation Foundation", etc.). There have been various attempts to create such a cooperation by both governments and by private corporations as economic solution is perhaps the strongest guarantee for peace to endure.

Results and Discussion. It is undeniable that the international system, and the interactions within have greatly changed. Unexpectedly, change in the international system comes with 
every major technological outbreak, geographical and territorial reconfiguration and global ideological paradigm-shifts.

These changes we have witnessed since the 1980 s, have changed the nature of global politics and diplomacy. If anything, diplomacy today is the same art it used to be, however, its instruments and responsibilities have changed.

Diplomacy has always been about engaging relevant actors to solve relevant issues or achieve relevant objectives. Aggressive, defensive or peaceful by nature; economic, military, social or cultural, these objectives have evolved. The most significant evolution however lies in the players.

Engaging relevant actors yesterday meant engaging states, connectors, individuals with access to a state or the specific part of a state, but today it has changed. Engaging relevant actors means anything, from a general, to a journalist. It can be directed to a small community of women fighting radicalization in Mali, as it can be directed towards an artistic centre in Lima, or an audience of millions of individuals through social media. Its means can involve a traditional phone call between two heads of states, as it can take the shape of an international football game between France and England in the aftermath of a terrorist attacks, as it can be condensed into 140 characters on twitter, or a picture on Facebook [8].

A relevant diplomacy today is a diplomacy that understands and appreciates that these are networks, and that successfully achieving its means and objectives require engaging these networks, creating them and activating them when relevant, because a group like Al Qaeda can have the network require to shake the heart of a global power like the United States for a day or few years, as a country like Norway can spend more on environmental and human development than the two or three largest economies combined.

These are, in short, examples of the power of network diplomacy, and thus, for good or bad, an illustration of its necessity in a highly fragmented, decentralized world, where audiences constantly shift, and means always evolve.

Speaking about the Israeli-Palestinian conflict itself it can be considered not as a single discrete unit but rather a problem set which allows for the solution of individual tasks (e.g. water management in Baka el Sharkia and Baka elGharbia Jat) without the umbrella of an overarching solution of the entire conflict. Diverse, multi-level actors in the context of network diplomacy are uniquely suited to tackle these issues which may be of too little importance, contrary to state policy or better approached by more agile organizations than classic rigid state institutions.

An agglomeration of thus solved problem sets reduces points of conflict and paves the road towards peace building. A lack of trust is a key inhibitor to the peace process, communication barriers extend beyond ideological considerations to tangible obstacles (e.g. a lack of channels, knowledge) which may inhibit the mere initiation of dialogue. To this end shared educational institutions, e.g. the AIES, may contribute to the establishment of feasible bilateral communication channels beyond state-to-state communication; the latter appears unlikely to yield a solution without an exogeneous shock.

A network of actors may push government towards adopting initiatives stemming from cooperation beyond classic state-to-state approaches. To this end the Good Water Neighbours project provides an illustrative example of civil cooperation, via a shared Palestinian-Israeli NGO, which has fostered cooperation on the municipal level.

Non-state actors may conduct their operations independent of overarching conflict on the state-to-state level and as such preserve ties and prevent the flaring up of conflicts in their respective arenas. Both Good Water Neighbours and the AIES have continued to operate throughout the crises of the late $20^{\text {th }}$ and to date $21^{\text {st }}$ century, including the second Intifada, whereas state-to-state communication had come to a standstill.

\section{REFERENCES}

1. Brooks D.B., Trottier J. De-Nationalization and De-Securitization of Transboundary Water Resources: The Israeli-Palestinian Case. International Journal of Water Resources Development, 2014, no. 30(2), pp. 211-223.

2. Cleveland W.L., Bunton M. A History of the Modern Middle East. Westview Press, 2016. 602 p.

3. Cohen H. Joint Israeli-Palestinian Political Activity in Jerusalem: Characteristics and Challenges. Locating Urban Conflicts. Palgrave Macmillan UK, Basingstoke, Hampshire, 2013. 269 p.

4. Coskun B.B. Cooperation over Water Resources as a Tool for Desecuritisation: The Israeli- 


\section{ДИПЛОМАТИЯ И ВОЕННЫЕ КОНФЛИКТЫ}

Palestinian Environmental NGOs as Desecuritising Actor. European Journal of Economic and Political Studies, 2016, no. 2 (2), pp. 97-115.

5. Golay F., Ziegler S., Harari N., Métaireau B., Carneiro C., Schuler M. Academic Cooperation to Foster Research and Advocacy Competences in the Occupied Palestinian Territory (West Bank). Technologies for Sustainable Development, Springer International Publishing, Switzerland, 2014. 303 p.

6. Ide T., Frölich C. Water Conflict or Water Cooperation? A Discursive Understanding of Water Conflict and Cooperation in Israel and Palestine. Norwich Conference on Earth System Governance, New Zealand, 2014, pp. 25-33.

7. Malul M., Bar-El R., Schwartz D. Patterns of Cooperation in High-Tech - Constraints, Feasibility, and Benefits: Results of a Study Among Palestinians and Israelis. Conflict Management and Peace Science, 2010, no. 27 (1), pp. 75-92.

8. Martins B. O. The EU Against the New Normal: Avoiding the Banalization of the IsraeliPalestinian Dispute. Mediterranean Politics, 2016, no. 21 (3), pp. 1-5.
9. McConnell F., Megoran N., Williams Ph. Geographies of Peace. New Approaches to Boundaries, Diplomacy and Conflict Resolution. London, I.B. Tauris, 2014. $320 \mathrm{p}$.

10. Metzl J.F. Network Diplomacy. Georgetown Journal of International Affairs, 2001, no. 2, p. 77.

11. Miller B. 1: One State or Two: Why a TwoState Solution Is Desirable, Necessary, and Feasible. Ethnopolitics, 2016, no. 15 (4), pp. 438-452.

12. Seidel T., AbuNimer M. Peace and Reconciliation Processes. The Wiley Blackwell Encyclopedia of Race, Ethnicity, and Nationalism, Springer International Publishing, Switzerland, 2016. $2520 \mathrm{p}$.

13. Springer J.E. Assessing Donor-Driven Reforms in the Palestinian Authority: Building the State or Sustaining Status Quo? Journal of Peacebuilding \& Development, 2015, no. 10 (2), pp. 1-19.

14. Voltolini B. The Role of Non-State Actors in EU Policies Towards the Israeli-Palestinian Conflict. Paris, France, European Union Institute for Security Studies, 2012. $47 \mathrm{p}$.

\section{Information About the Author}

Vladimir M. Morozov, Candidate of Sciences (History), Associate Professor, Department of the Diplomatic Service, Vice-Rector for Personnel Policy, MGIMO University, Prosp. Vernadskogo, 76, 119454 Moscow, Russian Federation, morozov@inno.mgimo.ru, https://orcid.org/0000-0003-2429-9150

\section{Информация об авторе}

Владимир Михайлович Морозов, кандидат исторических наук, доцент кафедры дипломатии, проректор по кадровой политике, Московский государственный институт международных отношений (университет) МИД России, просп. Вернадского, 76, 119454 г. Москва, Российская Федерация, morozov@inno.mgimo.ru, https://orcid.org/0000-0003-2429-9150 